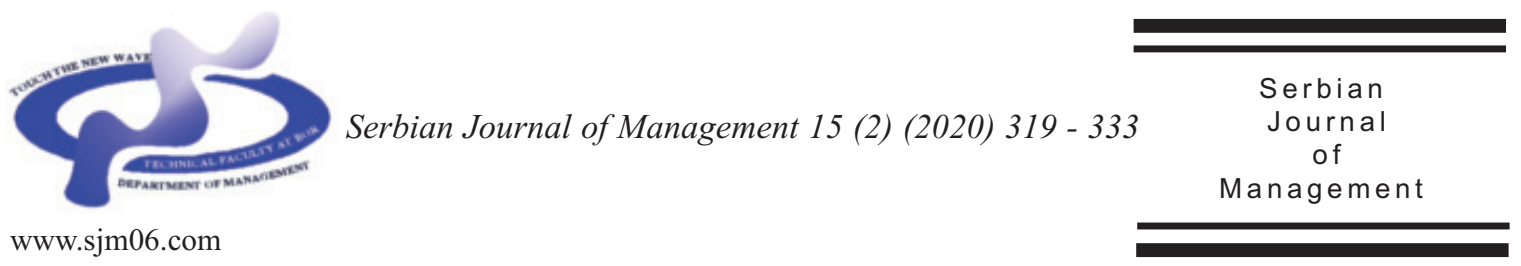

\title{
MODERATING EFFECT OF DEMOGRAPHIC AND BUSINESS CHARACTERISTICS ON PERFORMANCE OF WOMEN OWNED SMALL ENTERPRISES: EMPIRICAL EVIDENCE FROM INDIA
}

\author{
Mohan Vasan \\ A. Veeriya Vandayar Memorial Sri pushpam College \\ (Autonomous), Poondi - 613503 Thanjavur Dist Tamil Nadu, India
}

(Received 29 May 2019; accepted 15 July 2020)

\begin{abstract}
This study aims to explore the moderating effect of demographic and business characteristics on the performance of women-owned small enterprises. The theoretical and existing literature supports the moderating effect of demographic and business characteristics on business performance. The study adopted the descriptive research method. The primary data was gathered from 340 women owners of small enterprises and surveyed through a structured questionnaire. The Liner multiple regression was used to test the hypotheses. The findings of the study reveal that demographic characteristics such as father's occupation, education, and experience were significantly associated with business performance. Hence, age and marital status were not significantly associated with the business performance of women-owned small enterprises. Business characteristics such as the age of business, location of the business, and type of business were significantly associated with business performance.
\end{abstract}

Keywords: business characteristics, business performance, demographic characteristics, small enterprises, women entrepreneur

\section{INTRODUCTION}

In India, Small and Medium-sized Enterprises (SMEs) play a significant role in accelerating economic growth and employment generation. SMEs are considered as a trajectory for social transformation. 63.39 million enterprises are functioning across the nation and provide employment opportunities to 86.5 million people. It contributes $43 \%$ to India's GDP. Thus, $20.37 \%$ of units are owned by women and $51.25 \%$ of units are functioning in rural areas. Furthermore, it immensely contributes to attaining the inclusive growth agenda of India (Government of India, 2018). This

\footnotetext{
"Corresponding author:drvasanm@gmail.com
}

DOI: $10.5937 /$ sjm15-21922 
sector fuels the growth of industrial entrepreneurship. India's SME sector is extremely varied in terms of firm size, level of technology adoption, and heterogeneous products and services. It assists as auxiliary units to large-scale industries (Lama, 2013).

In developing countries, the womenowned small business firms have been extremely contributed to the economic development of the nation and contribute a major part in the family income (Vasan, 2016; Yoganandan \& Sivasamy, 2016; Shiralashetti, 2017). The performance of small firms depends upon the availability of resources. In the resource-based view, a firm's competitive advantage is concerned with unique and valuable resources (Hart, 1995; Hunt, 1996; Yoganandan \& Vignesh, 2017). In this viewpoint, this study emphasizes that demographic and business characteristics are considered as unique and valuable resources. It contributes to the sustainable competitive advantage that plays a vital role in the firm's performance. Hence, earlier studies focused on business skills, financial performance, and problems of small business firms. Only a few studies were focused on the effect of demographic and business characteristics on business performance. So, the present study has been analyzed the effect of demographic and business characteristics on the performance of women-owned small enterprises.

\section{LITERATURE REVIEW}

2.1. Effect of Demographic Characteristics on Business Performance

The demographic characteristics of an entrepreneur play a significant role in the performance of a business. Several earlier studies found that demographic characteristics such as age, marital status, father's occupation, education, and previous experience have influenced in the performance of small enterprises.

\subsubsection{Age and Business Performance}

The entrepreneur's age is an important variable that affects the growth of SMEs. Reynolds et al., (2000) examined that young individual was more active in entrepreneurial activities. Sinha (1996) divulged that successful entrepreneurs were at a young age. Kristiansen et al., (2003) identified that there was a significant correlation between entrepreneurs' age and business success. Salia (2017) identified that the age of owners was positively correlated with the performance of women-owned microenterprises. Zahra (2013) in his study found that the performance of business run by young age women entrepreneurs was better and they were earned more income from business operations. Similar results were stated by Rasheed (2002), and Stevenson and Jarillo (1990). Islam et al., (2011) examined that age had a significant effect on the success of SMEs. Conversely, age was not related to the performance of small firms (Stuart \& Abetti, 1990; Bertaut \& StarrMcCluer, 2000; Antoncic, 2009). Agarwal and Gort (2002) found that the age of owners was positively related to the performance of small firms. Thus, the following hypothesis was framed:

H1. There is a significant relationship between the age and performance of womenowned small enterprises. 
2.1.2. Marital Status and Business Performance

Earlier studies have yielded mixed results, confirming the impact of the marital status of entrepreneurs on business performance. Jennings \& Beaver (1997), Chen et al., (2005), and Bell et al., (2011) noted that marriage was restricted the success of women-owned business firms due to their family commitments. But, the result of studies conducted by Aderemi et al., (2008) and Adegbite et al., (2007) revealed that business run by married women was performed better than unmarried. Salia (2017) revealed that the performance of micro-enterprises owned by married women was high than a business run by single women. Olson et al., (2003) found that marital status had not significantly influenced the business performance. Accordingly, the following hypothesis was framed:

H2. There is a significant relationship between marital status and performance of women-owned small enterprises.

\subsubsection{Father's Occupation and Firm Performance}

The knowledge required for doing business can be acquired by observing others. The children of entrepreneurs can easily start a business than other people because of family background they got exposure and skills (Niittykangas \& Tervo, 2005; Kim et al., 2006; Sorensen, 2007). Several studies found that the father's occupation is considered as a key factor that influenced the firms' performance (Scott \& Twomey, 1988; Brown, 1990). The studies conducted by Duchesneau \& Gartner (1990),
Cooper et al., (1992), and Mungai and Velamuri (2010) proved that the children of entrepreneurs can form and run the business firms successfully than other people. If any business problems, they can easily acquire managerial skills, easy access to market, and other business-related information from their parents (Ardichvili et al., 1998; Krauss et al., 2005; Mungai \& Velamuri, 2010). Isaga (2015) identified that entrepreneurial family background positively influenced on the performance of SMEs. Accordingly, the following hypothesis was framed:

H3. There is a significant relationship between father's occupation and the performance of women-owned small enterprises.

\subsubsection{Education and Business Performance}

Education is an important component of human capital (Becker, 1994). It brings skills, knowledge, ability, motivation, and self-confidence (Cooper et al., 1994). It is viewed as a key factor for the success of small firms (Yusuf, 1995; Wijewardena \& Cooray, 1996). Education was significantly related to the performance of SMEs (Kirby, 2003; Schrader \& Siegel, 2007; Wright et al., 2007; Unger et al., 2009). Sinha (1996) examined that education had played a significant role in entrepreneurial effectiveness. Similarly, Charney and Libecap (2000) identified that education had provided sufficient entrepreneurial skills. Islam et al., (2011) found that education had significantly influenced on business performance of SMEs. Salia (2017) identified that education was significantly related to the performance of women-owned micro-enterprises. Lucas (2017) found that 
level of education was significantly improved the firm's performance. Accordingly, the following hypothesis was framed:

H4. There is a significant relationship between education and performance of women-owned small enterprises.

\subsubsection{Previous Experience and Business Performance}

Like education, previous experience is also one of the important components which helps to improve business skills (Ucbasaran et al., 2008). Hence, it facilitates to understand market conditions, gather market information, network building, and improve managerial competencies (Basu \& Goswami, 1999; Shane, 2004; Dobbs \& Hamilton, 2007). Prior experience had determined the performance of micro-enterprises. The earlier studies portrayed that entrepreneurs with prior experience can be gathered much more valuable information concerned with business formation and growth (Politis, 2005; Unger et al., 2009). Kolvereid (1996) found that previous entrepreneurial experience had significantly influenced in entrepreneurial intentions than inexperienced individuals. The success of small firms had significantly related to prior experience (Yusuf, 1995; Wijewardena \& Cooray, 1996; Islam et al., 2011). Past experiences in the specific business had positively influenced in the performance of firms (Loscocco et al., 1991; Bosma et al., 2004). Accordingly, Rauch and Frese (2000) identified that previous experience was significantly increased the number of contacts with contractors, suppliers, and customers. Brush and Chaganti (1999) found that the firm's performance was significantly influenced by previous experience. Accordingly, the following hypothesis was framed:

H5. There is a significant relationship between previous experience and performance of women-owned small enterprises.

\subsection{Effect of Business Characteristics on Business Performance}

Literature discloses that the performance of women-owned enterprises influenced by certain business characteristics namely the age of business, location of the business, and type of business.

\subsubsection{Age of Business on Business Performance}

The age of business firms significantly connected with the learning experience of the entrepreneurs. Old firms possibly learned more things from their experience. Sleuwaegen and Goedhuys (2002) found that the firm's age was determined the business growth and performance. Kristiansen et al., (2003) identified that the longevity of business operations was significantly related to business performance. Islam et al., (2011) examined that the age of the organization was significantly related to the performance of SMEs. Additionally, several studies found that firms' age was significantly related to business performance (Antoncic, 2009; Lucas, 2017). Accordingly, the following hypothesis was framed:

H6. There is a significant relationship between the age of business and the performance of women-owned small enterprises. 
2.2.2. Location of Business on Business Performance

The location of a business is an important component that determines the business performance. It was significantly related to business success (Alli et al., 1991). Aderemi et al., (2008) found that the location of business had positively influenced in the performance of women-owned microenterprises. Salia (2017) identified that there was no significant difference in the performance of women-owned microenterprises functioning in city centers and industrial areas. Accordingly, the following hypothesis was framed:

H7. There is a significant relationship between the location of the business and the performance of women-owned small enterprises.

\subsubsection{Type of Business on Business Performance}

The type of business is a key factor in determining the performance of womenowned micro-enterprises. Abor and Biekpe (2006) revealed that women were mostly involved in small level entrepreneurial activities. Hence, only a few women have engaged in manufacturing or technologyrelated businesses (Mazzarol et al., 1999). According to Rutashobya (1995), most of the women entrepreneurs had involved in food processing, retail, textile, clothing, and service-oriented firms. Similarly, a research study conducted by the ILO (2003) shown that women were mostly engaged in service and retail businesses like beauty salons, food vending, decorations, catering, pottery, and basket making. The study also found that only a few women were involved in less capital-intensive manufacturing units like batik making, tailoring, and food processing. Salia (2017) found that type of business was significantly related to the performance of women-owned micro-enterprises. Accordingly, the following hypothesis was framed:

H8. There is a significant relationship between the type of business and the performance of women-owned small enterprises.

\section{RESEARCH METHODOLOGY}

The descriptive method of research was adopted to measure the effect of demographic and business characteristics on the performance of women-owned small enterprises in the Coimbatore region of Tamilnadu, India. This region was purposively selected because relatively a greater number of women have engaged in entrepreneurial activities than other cities in India. The descriptive method of research is a logical approach because the data comprised the actual expression of the respondents, which was collected through a survey questionnaire. Under this method of data collection, there is a lesser chance of bias. The questionnaire was circulated to 340 women owners of small enterprises. The survey questionnaire comprises demographic characteristics, business characteristics, and business performance. The demographic characteristics include age, marital status, father's occupation, education, and experience. The business characteristics cover the age of business, location of the business, and type of business. The business performance is measured using business growth, 
profitability, competitive advantage, and manageable which is measured by using a 5point Likert scale of $1=$ 'very poor' to $5=$ 'very good' (Becchetti \& Trovoto, 2002). The data collected from the women entrepreneurs were analyzed using the Statistical Package for Social Science (SPSS). The demographic and business characteristics were presented using descriptive statistics. Friedman's test was used to measure firm performance. Linear multiple regression was applied to examine the relationship between demographic and business characteristics and business performance. This tool is a widely accepted technique to find the strength of the effect of independent variables on the dependent variable (Freedman, 2009; Rencher \& Christensen, 2012).

\section{RESULTS}

\subsection{Demographic and Business Characteristics of the Women Entrepreneurs}

Demographic characteristics of women entrepreneurs indicate that among four age groups, the respondents falling in the age group of $31-40$ years $(27.9 \%)$ and $41-50$ years $(25.9 \%)$ were abounding in the sample. Thus, young and middle-aged respondents were identified as active age groups to undertake entrepreneurial risks. The majority of the respondents $(62.1 \%)$ were shouldering marital responsibilities. Business inheritance of the respondents was observed that most of them $(66.5 \%)$ continued their fathers' occupation. $42.1 \%$ of the respondents have completed school level education, $27.4 \%$

Table 1. Demographic and Business Characteristics

\begin{tabular}{lllrl}
\hline \multirow{2}{*}{ Criteria } & \multicolumn{1}{c}{ Variables } & \multicolumn{1}{c}{ Categories } & Frequency & \% \\
\hline Demographic & Age & Below 30 & 81 & 23.8 \\
Characteristics & (in years) & $31-40$ & 95 & 27.9 \\
& & $41-50$ & 88 & 25.9 \\
& & Above 50 & 76 & 22.4 \\
\cline { 2 - 5 } & Marital & Single & 129 & 37.9 \\
& Status & Married & 211 & 62.1 \\
\cline { 2 - 5 } & Father's & Salaried & 114 & 33.5 \\
& Occupation & Business & 226 & 66.5 \\
\cline { 2 - 5 } & Education & School & 143 & 42.1 \\
& & Graduation & 93 & 27.4 \\
& & Post-Graduation & 104 & 30.6 \\
\cline { 2 - 5 } & Experience & Yes & 125 & 36.8 \\
& & No & 215 & 63.2 \\
\hline Business & Age of & Below 5 & 131 & 38.5 \\
& Business & 6-10 & 87 & 25.6 \\
& (in years) & 11-15 & 75 & 22.1 \\
& & Above 15 & 47 & 13.8 \\
\cline { 2 - 5 } & Location of & Home & 62 & 18.2 \\
& Business & Roadside & 118 & 34.7 \\
& & Market & 79 & 23.2 \\
& & Industrial areas & 81 & 23.8 \\
\hline & Type of & Service & 133 & 39.1 \\
& business & Retail & 37.6 \\
& & Manufacturing & 23.2 \\
\hline
\end{tabular}


were graduates, and $30.6 \%$ were postgraduates. The majority of the sample women entrepreneurs $(63.2 \%)$ were no previous business experience.

Business characteristics of women-owned small enterprises show that $38.5 \%$ of them were running below 5 years old enterprises. $34.7 \%$ of respondents engaged in roadside business, and $18.2 \%$ of the women entrepreneurs were running a home-based business. Service and retail entrepreneurial units were operated by the women entrepreneurs and $23.2 \%$ of them only involved in running manufacturing units (Table 1).

\subsection{Business Performance}

The terms business performance and business success are interchangeably used in earlier studies. The firm performance is an actual outcome (March \& Sutton, 1997). In this study, the performance of women-owned small enterprises has measured in terms of business growth, profitability, competitive advantage, and manageable (Becchetti \& Trovoto, 2002). Friedman's test is used to measure business performance.

The $\chi^{2}$ test statistic was 38.413. It was significant at a $5 \%$ level $(p \leq 0.05)$. It inferred that there was a significant difference in the parameters of business performance. The mean rank shows that the business owned by women entrepreneurs was earned good profit followed by manageable, business growth, and competitive advantage (Table 2).

\subsection{Effect of Demographic and Business Characteristics on Performance of Women-Owned Small Enterprises}

Multiple linear regression analysis was used to determine whether demographic and business characteristics (independent variable) have any significant effect on the business performance of women-owned small enterprises (dependent variable). The result of regression analysis is presented in Tables 3 and 4 .

The effect of demographic characteristics on business performance divulges that the Adjusted $R^{2}$ value was .491 which implied that $49.1 \%$ of the variation in the dependent variable was explained by the independent variables included in the model. This result reveals that the model was a strong predictor. The R-value was 0.751 which shows that there was a strong positive correlation between the dependent variable (Business performance) and the set of independent

Table 2. Business Performance

\begin{tabular}{lccccc}
\hline \multicolumn{1}{c}{ Variables } & $\overline{\mathbf{x}}$ & $\boldsymbol{\sigma}$ & Mean Rank & $\chi^{2}$ & Sig. \\
\hline Business growth & 4.42 & .710 & 2.58 & 38.413 & .000 \\
Profitability & 4.45 & .615 & 2.60 & & \\
Competitive advantage & 4.24 & .666 & 2.21 & & \\
Manageable & 4.43 & .719 & 2.60 & & \\
\hline
\end{tabular}

Table 3. Model Summary

\begin{tabular}{lccccc}
\hline \multicolumn{1}{c}{ Dimensions } & $\mathbf{R}$ & $\mathbf{R}^{\mathbf{2}}$ & Adj. $\mathbf{R}^{\mathbf{2}}$ & $\mathbf{F}$ & Sig. \\
\hline Effect of Demographic Characteristics & .751 & .564 & .491 & 6.807 & .000 \\
\hline Effect of Business Characteristics & .639 & .408 & .385 & 4.054 & .000 \\
\hline
\end{tabular}


Table 4. Regression Coefficients

\begin{tabular}{llcccccc}
\hline \multirow{2}{*}{ Dimensions } & \multicolumn{1}{c}{ Variables } & \multicolumn{2}{c}{$\begin{array}{c}\text { Unstandardized } \\
\text { Coefficients }\end{array}$} & $\begin{array}{c}\text { Standardized } \\
\text { Coefficients }\end{array}$ & \multirow{2}{*}{ t } & Sig. \\
\cline { 3 - 5 } & & $\mathbf{B}$ & S.E. & $\boldsymbol{\beta}$ & & \\
\hline Effect of & Constant & 16.479 & .597 & & 27.619 & .000 \\
Demographic & Age & -.061 & .152 & -.025 & -.401 & .688 \\
Characteristics & Marital Status & -.376 & .316 & -.073 & -1.189 & .236 \\
& Father's Occupation & .106 & .131 & .092 & .808 & .020 \\
& Education & .311 & .287 & .113 & 1.143 & .006 \\
& Experience & .580 & .274 & .164 & 2.117 & .015 \\
\hline Effect of Business Constant & 16.479 & .597 & & 27.619 & .000 \\
Characteristics & Age of Business & .261 & .152 & .125 & 1.401 & .012 \\
& Location of Business & -.011 & .274 & -.134 & -2.117 & .035 \\
& Type of Business & -.376 & .316 & -.173 & -1.589 & .006 \\
\hline
\end{tabular}

variables. The $\mathrm{F}$ statistic (6.807) for the model was statistically significant at a $5 \%$ level $(p \leq 0.05)$. Therefore, the overall model was significant. The regression coefficient indicated that the father's occupation $(\beta=.092, t=.808, p \leq 0.05)$, education $(\beta=.113$, $t=1.143, p \leq 0.05)$, and experience $(\beta=.164$, $t=2.117, \quad p \leq 0.05) \quad$ were significantly associated with the business performance of women-owned small enterprises. Hence, age and marital status were not significantly associated $(p>0.05)$ with the business performance of women-owned small enterprises. Therefore, H3, H4, and H5 were supported whereas $\mathrm{H} 1$ and $\mathrm{H} 2$ were not supported. The effect of demographic characteristics on the performance of women-owned small enterprises was diagrammatically presented in Figure 1.

The effect of business characteristics on business performance delineates that the Adjusted $R^{2}$ value was 0.385 which implied that $38.5 \%$ of the variation in the dependent variable was explained by the independent variables included in the model. This result indicates that the model was a strong predictor. The R-value was .639 which shows that there was a strong positive correlation between the dependent variable
(Business performance) and the set of independent variables. The F statistic (4.054) for the model was statistically significant at a $5 \%$ level $(p \leq 0.05)$. Thus, the overall model was significant. The regression coefficient indicates that the age of business $(\beta=.125$, $t=1.401, p \leq 0.05)$, location of the business ( $\beta=-.134, t=-2.117, p \leq 0.05)$, and type of business $(\beta=-.173, t=-1.589, p \leq 0.05)$ were significantly associated with the business performance of women-owned small enterprises. Hence, the age of business increased the business performance of women-owned small enterprises and the location of business and type of business were decreased the business performance of women-owned small enterprises. Therefore, H6, H7, and H8 were supported. The effect of business characteristics on the performance of women-owned small enterprises was diagrammatically presented in Figure 2.

\section{DISCUSSION}

The study revealed that age was not significantly associated with the business performance of women-owned small 


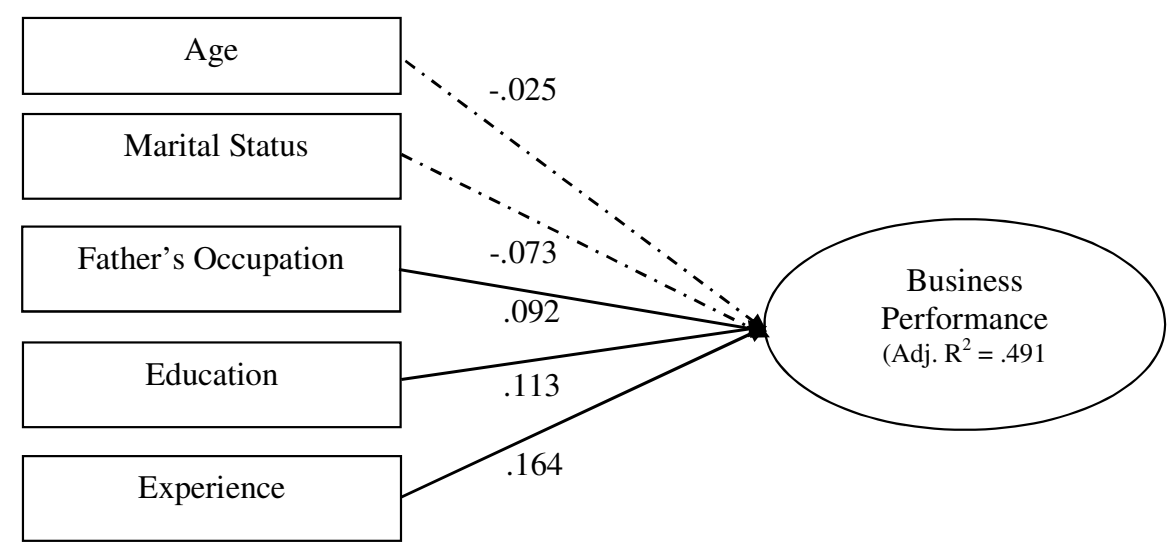

Figure 1: Effect of Demographic Characteristics on Performance of Women-Owned Small Enterprises

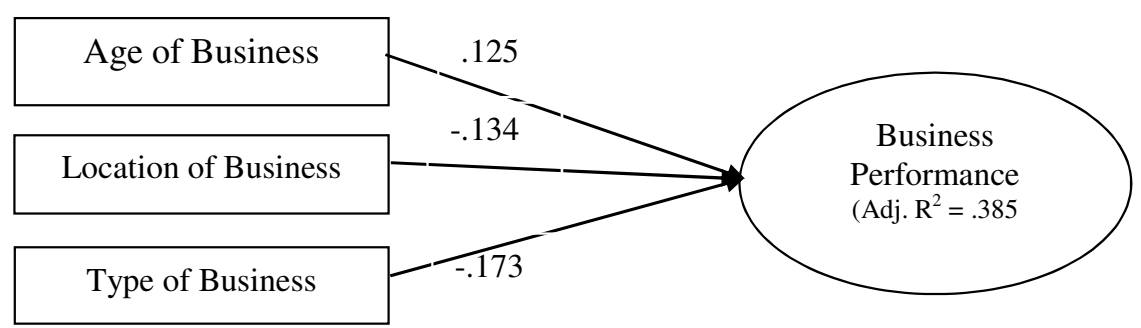

Figure 2: Effect of Business Characteristics on Performance of Women-Owned Small Enterprises

enterprises. It indicated that business performance was not related to the age of the entrepreneurs. This result supports the findings of several previous studies (Stuart \& Abetti, 1990; Bertaut \& Starr-McCluer, 2000; Antoncic, 2009).

Marital status was not significantly associated with the business performance of women-owned small enterprises. It proved that marriage was not restricted the business performance. This result in line with a study conducted by Olson et al., (2003).

Father's occupation was significantly associated with the business performance of women-owned small enterprises. It indicated that women entrepreneurs whose father was engaged in business operations were positively related to business performance. This finding was in line with the studies conducted by Scott and Twomey (1988),
Brown (1990), and Isaga (2015).

The study identified that education was positively related to the business performance of women-owned small enterprises. It proved that business success was determined by the level of education. This result corroborates several previous studies (Kirby, 2003; Schrader \& Siegel, 2007; Wright et al., 2007; Unger et al., 2009; Salia, 2017).

It was found that experience was significantly associated with the business performance of women-owned small enterprises. It infers that previous experience was an advantage to the entrepreneurs. Experience provided adequate knowledge about business. Similar findings were reported by Kirby (2003), Schrader and Siegel (2007), Wright et al., (2007), Unger et al., (2009) and Lucas (2017). 
The study results showed that the age of business was significantly associated with the business performance of women-owned small enterprises. It depicts that age-old business firms were performed well than younger ones. The findings substantiate several previous studies (Sleuwaegen \& Goedhuys, 2002; Kristiansen et al., 2003; Antoncic, 2009; Islam et al., 2011; Lucas, 2017).

The location of the business was significantly associated with the business performance of women-owned small enterprises. Hence, business location decreases firm performance. It denotes that the business location determines the success of a firm. A similar result was reported by Aderemi et al., (2008).

Lastly, the study revealed that type of business was significantly associated with the business performance of women-owned small enterprises. Hence, the type of business was decreased firm performance. It inferred that type of business is the main criterion for the success of a business. The study findings support the earlier studies whose findings revealed that type of business significantly associated with business performance (Abor \& Biekpe, 2006; Salia, 2017).

\section{CONCLUSION}

The study attempted to identify whether demographic and business characteristics affect the performance of women-owned small enterprises in India. In short, the study findings showed that demographic characteristics such as father's occupation, education, and experience were affected the business performance. Business characteristics such as the age of business, location of the business, and type of business were affected the business performance. Therefore, the study concluded that demographic and business characteristics were significantly related to the performance of women-owned small enterprises. The study findings are helpful to entrepreneurs for understanding the factors affecting business performance.

Based on the study findings, some recommendations are offered for the betterment of small enterprises. First, the study identified that the location of a business significantly affects business performance. So, the government should provide a separate space in the center of city/ town for women entrepreneurs to do their business. Second, the study findings reported that education and previous experience significantly relates to business performance. So, the District Industrial Corporations and Entrepreneurship Development Institutes should provide short-term training programs for equipping women entrepreneurs. Lastly, study findings showed that fewer women were involved in manufacturing businesses due to a lack of financial support. So, the study recommended that a micro-credit scheme through subsidized loans should be given to start small manufacturing firms.

\section{References}

Abor, J., \& Biekpe, N. (2006). SMEs' Access to Debt Finance: A Comparison of Male-Owned and Female-Owned Businesses in Ghana. International Journal of Entrepreneurship and Innovation, 7 (2), 105112.

Adegbite, S.A., Ilori, M.O., Irefin, I.O., Abereijo, I.O. \& Aderemi, H.O.S. (2007). Evaluation of the Impact of Entrepreneurial 


\title{
ПОСРЕДНИ ЕФЕКАТ ДЕМОГРАФСКИХ И ПОСЛОВНИХ КАРАКТЕРИСТИКА НА РЕЗУЛТАТЕ МАЛИХ ПРЕДУЗЕЋА У ВЛАСНИШТВУ ЖЕНА: ЕМПИРИЈСКИ ДОКАЗИ ИЗ ИНДИЈЕ
}

\author{
Mohan Vasan
}

\section{Извод}

Циљ ове студије је да истражи посредни ефекат демографских и пословних карактеристика на перформансе малих предузећа у власништву жена. Теоријска и постојећа литература подржава посредни ефекат демографских и пословних карактеристика на пословне перформансе. Студија је усвојила дескриптивну методу истраживања. Примарни подаци прикупљени су од 340 жена власница малих предузећа које су анкетиране путем структурираног упитника. Линерна вишеструка регресија коришћена је за тестирање хипотеза. Налази студије откривају да су демографске карактеристике као што су очево занимање, образовање и искуство биле значајно повезане са пословним учинком. C' друге стране, старост и брачни статус нису били значајно повезани са пословним учинком малих предузећа у власништву жена. Карактеристике предузећа попут старости, локације и врсте посла биле су у значајној вези са пословним учинком.

Кључне речи: пословне карактеристике, пословни учинак, демографске карактеристике, мала предузећа, жене предузетнице

Characteristics on the Performance of Small Scale Manufacturing Industries in Nigeria. Journal of Asia Entrepreneurship and Sustainability, 3 (1), 1-22.

Aderemi, H.O, Ilori, M.O, Siyanbola, W.O, Adegbite, S.A., \& Abereijo I.O. (2008). An Assessment of the Choice and Performance of Women Entrepreneurs in Technological and Non-technological Enterprises in South-Western Nigeria. African Journal of Business Management, 2 (10), 165-176.

Agarwal, R., \& Gort, M. (2002). Firm and Product Life Cycles and Firm Survival. The American Economic Review, 92 (2), 184190.

Alli, K. L., Ramirez, G.G., \& Yung, K. (1991). Corporate Headquarters Relocation: Evidence from the Capital Markets. Journal of the American Real Estate and Urban Economics Association 19 (4), 583-600.
Antoncic, B. (2009). The Entrepreneur's General Personality Traits and Technological Developments. World Academy of Science, Engineering and Technology, 53, 236-241.

Ardichvili, A., Cardozo, R., \& Ray, S. (2003). A Theory of Entrepreneurial Opportunity Identification and Development. Journal of Business Venturing, 18 (1), 105-123.

Basu, A., \& Goswami, A. (1999). South Asian Entrepreneurship in Great Britain: Factors Influencing Growth. International Journal of Entrepreneurial Behaviour and Research, 5 (5), 251-275.

Becchetti, L., \& Trovato, G. (2002). The Determinants of Growth for Small and Medium-Sized Firm. The Role of the Availability of External Finance. Small Business Economics, 19 (4), 291-306.

Becker, G.S. (1994). Human Capital: A Theoretical and Empirical Analysis with 
Specific Reference to Education, Third Edition. University of Chicago Press. Chicago. USA

Bell, S.T., Villado, A.J., Lukasik, M.A., Belau, L., \& Briggs, A.L. (2011). Getting Specific about Demographic Diversity and Team Performance Relationships: A MetaAnalysis. Journal of Management, 37 (3), 709-743.

Bertaut, C.C., \& Starr-McCluer, M. (2000). Household portfolios in the United States. Finance and Economics Discussion Series 2000-26, Board of Governors of the Federal Reserve System (U.S.) Retrieved $\mathrm{f}$ o $m$ https://ideas.repec.org/p/fip/fedgfe/200026.html

Bosma, N., Van Praag, M., Thurik, R., \& De Wit, G. (2004). The Value of Human and Social Capital Investments for the Business Performance of Start-ups. Small Business Economics, 23 (3), 227 - 236.

Brown, R. (1990). Encouraging Enterprise: Britain's Graduate Enterprise Program. Journal of Small Business Management, 28 (4), 71-77.

Brush, C.G., \& Chaganti, R. (1999). Business without Glamour? An Analysis of Resources on Performance by Size and Gender in Small Service and Retail Firms. Journal of Business Venturing, 14 (3), 233257.

Charney, A., \& Libecap, G.D. (2000). Impact of Entrepreneurship Education: An Evaluation of the Berger Entrepreneurship Program at the University of Arizona, 19851999. Kauffman Center for Entrepreneurial Leadership. Final Report. Retrieved from https://citeseerx.ist.psu.edu/viewdoc/downlo ad?doi $=10.1 \cdot 1.584 .9846 \&$ rep $=$ rep $1 \&$ type $=p$ df

Chen, H.S., Beck, S.L., \& Amos, L.K. (2005). Leadership Styles and Nursing
Faculty Job Satisfaction in Taiwan. Journal of Nursing Scholarship, 37(4), 374-380.

Cooper, A.C., Folta, F., Gimeno-Gascon, F.J., \& Woo, C.Y. (1992). Entrepreneurs, Process of Founding and New Firm Performance. In Sexton, D., \& Kassandra, J. (Eds.), The State of the Art in Entrepreneurship. Boston, MA: PWS Kent Publishing Co. 301-340.

Cooper, A.C., Gimeno-Gascon, F.J., \& Woo, C.Y. (1994). Initial Human and Financial Capital as Predictors of New Venture Performance. Journal of Business Venturing, 9(5), 371-395.

Freedman, D.A. (2009). Statistical Models: Theory and Practice. Cambridge University Press.

Dobbs, M., \& Hamilton, R.T. (2007). Small Business Growth: Recent Evidence and New Directions. International of Entrepreneurial Behaviour and Research, 13 (5), 296-322.

Duchesneau, D., \& W. Gartner. (1990). A Profile of New Venture Success and Failure in an Emerging Industry. Journal of Business Venturing, 5 (5), 297-312.

Government of India. (2018). Annual Report of MSME, 2017-18. Ministry of Micro, Small and Medium Enterprises, New Delhi. Retrieved from https://msme.gov.in/sites/default/files/MSM E-AR-2017-18-Eng.pdf

Hart, S.L. (1995). A Natural-resourcebased View of the Firm. Academy of Management Review, 20 (4), 986-1014.

Hunt, S.D., \& Morgan, R.M. (1996). The Resource-advantage Theory of Competition: Dynamics, Path Dependencies, and Evolutionary Dimensions. The Journal of Marketing, 60 (4), 107-114.

ILO. (2003). Jobs, Gender and Small Enterprise in Africa: Tanzanian Women Entrepreneurs - Going for Growth. ILO 
Office, Dar es Salaam and Ministry of Prospects. Business Studies, 33, 106-116.

Industry \& Trade, Geneva: International Labour Organization. Retrived from https://www.ilo.org/public/libdoc/ilo/2003/1 03B09 58 engl.pdf.

Islam, M.A., Khan, M.A., Obaidullah, A.Z.M., \& Alam, M.S. (2011). Effect of Entrepreneur and Firm Characteristics on the Business Success of Small and Medium Enterprises (SMEs) in Bangladesh. International Journal of Business and Management, 6 (3), 289-299.

Jennings, P., \& Beaver, G. (1997). The Performance and Competitive Advantage of Small Firms: A Management Perspective. International Small Business Journal, 15 (2), 63-75.

Kim, P., Aldrich, H., \& Keister, L. (2006). Access (Not) Denied: The Impact of Financial, Human, and Cultural Capital on Entrepreneurial Entry in the United States. Small Business Economics, 27 (1), 5-22.

Kirby, A.D. (2003). Entrepreneurship. McGraw-Hill Education, Maidenhead.

Kolvereid, L. (1996). Prediction of Employment Status Choice Intentions. Entrepreneurship Theory and Practice, 21 (1), 47-58.

Krauss, S.I., Frese, M., Friedrich, C., \& Unger, J.M. (2005). Entrepreneurial Orientation: A Psychological Model of Success among Southern African Small Business Owners. European Journal of Work and Organizational Psychology, 14 (3), 315344.

Kristiansen, S., Furuholt, B., \& Wahid, F. (2003). Internet Cafe Entrepreneurs: Pioneers in Information Dissemination in Indonesia. The International Journal of Entrepreneurship and Innovation, 4 (4), 251263.

Lama, P., (2013). Micro, Small and Medium Enterprises in India - Problems and
Loscocco, K., Robinson, J., Hall, R., \& Allen, J. (1991). Gender and Small Business Success: An Inquiry into Women's Relative Disadvantage. Social Forces, 70 (1), 65-85.

March, J.G., \& Sutton, R.I. (1997). Crossroads-Organizational Performance as a Dependent Variable. Organization Science, 8 (6), 698-706.

Mazzarol, T., Volery, T., Doss, N., \& Thein, V. (1999). Factors Influencing Small Business Start-ups. International Journal of Entrepreneurial Behavior and Research, 5 (2), 48-63.

Mungai, E., \& Velamuri, S.R. (2010). Parental Entrepreneurial Role Model Influence on Male Offspring: Is It Always Positive and When Does It Occur? Entrepreneurship Theory and Practice, 35 (2), 337-357.

Niittykangas, H., \& Tervo, H. (2005). Spatial Variations in Intergenerational Transmission of Self-employment. Regional Studies, 39 (3), 319-32.

Isaga, N., (2015). Owner-Managers' Demographic Characteristics and the Growth of Tanzanian Small and Medium Enterprises. International Journal of Business and Management, 10 (5), 168-181.

Olson, P.D., Zuiker, V.S., Danes, S.M., Stafford, K., Heck, R.K.Z., \& Duncan, K.A. (2003). The Impact of the Family and the Business on Family Business Sustainability. Journal of Business Venturing, 18 (5), 639666.

Politis, D. (2005). The Process of Entrepreneurial Learning: A Conceptual Framework. Entrepreneurship Theory and Practice, 29 (4), 399-424.

Rasheed, H.S. (2002). Developing Entrepreneurial Characteristics in Youths: The Effect of Education and Enterprise Experience. International Journal of 
Entrepreneurship Education, 2 (1), 21 - 36.

Rauch, A., \& Frese, M. (2000). Psychological approaches to entrepreneurial success. A general model and an overview of findings. In C.L. Cooper \& I.T. Robertson (Eds.), International Review of Industrial and Organizational Psychology. Wiley. Chichester. 101-142.

Rencher, A.C., \& Christensen, W.F. (2012). Methods of Multivariate Analysis, Wiley Series in Probability and Statistics, John Wiley \& Sons.

Reynolds, P.D., Hay, M., Bygrave, W.D., Camp, S.M., \& Autio, E. (2000). Global Entrepreneurship Monitor 2000 Executive Report: Babson College, Kauffman Center for Entrepreneurial Leadership, and London Business School. Retreived from https://www.researchgate.net/publication/27 3705139_Global_Entrepreneurship_Monitor _2000_Executive_Report

Rutashobya, L.H.K. (1995). Women in Business in Tanzania. In C. Creighton \& C.K. Omari (Eds.), Gender Family and the Household in Tanzania. Westport, Avebury, 269-281.

Lucas, S. (2017). The Impact of Demographic and Social Factors on Firm Performance in Kenya. Journal of Business and Economic Development, 2 (4), 255-261.

Schrader, R., \& Siegel, D.S. (2007). Assessing the Relationship between Human Capital and Firm Performance: Evidence from Technology-Based New Ventures. Entrepreneurship: Theory and Practice, 31 (6), 893-908.

Salia, P.J. (2017). The Influence of Selected Demographic and Business Characteristics on the Performance of Women-Owned Microenterprises in Tanzania. Saudi Journal of Business and Management Studies, 2 (3A), 169-178.

Scott, M.G., \& Twomey, D.F. (1988). The
Long-term Supply of Entrepreneurs: Students' Career Aspirations in Relation to Entrepreneurship. Journal of Small Business Management, 26 (4), 5-13.

Shane, S. (2004). A General Theory of Entrepreneurship: The IndividualOpportunity Nexus. Edward Elgar Publishing, Inc. Aldershot, Great Britan

Shiralashetti, A.S. (2017). Prospects and Problems of MSMEs in India - A Study. International Journal of Multidisciplinary and Academic Research, 1(2), 1-7.

Sinha, T.N. (1996). Human Factors in Entrepreneurship Effectiveness. The Journal of Entrepreneurship, 5 (1), 23-39.

Sleuwaegen, L., \& Goedhuys, M. (2002). Growth of Firms in Developing Countries, Evidence from Cote D'Ivoire. Journal of Development Economics, 68 (1), 117-135.

Sorensen, J.B. (2007). Closure and Exposure: Mechanisms in the Intergenerational Transmission of Selfemployment. Research in the Sociology of Organizations, 25, 83-124.

Stevenson, H.H., \& Jarillo, J.C. (1990). A Paradigm of Entrepreneurship: Entrepreneurial Management. Strategic Management Journal, 11 (1), 17- 27.

Stuart, R.W., \& Abetti, P.A. (1990). Impact of Entrepreneurial and Management Experience on Early Performance. Journal of Business Venturing, 5 (3), 151-162.

Ucbasaran, D., Westhead, P., \& Wright, M. (2008). Opportunity Identification and Pursuit: Does an Entrepreneur's Human Capital Matter? Small Business Economics, 30 (2), 153-173.

Unger, J.M., Rauch, A., Frese, M., \& Rosenbusch, N. (2009). Human Capital and Entrepreneurial Success: A Meta-analytical Review. Journal of Business Venturing, 26 (3), 341-358.

Vasan, M. (2016). Problems and 
Prospects of Women Entrepreneurs in India.

Shanlax International Journal of

Management, 3 (1), 312-315.

Wijewardena, H., \& Cooray S. (1996). Factors Contributing to the Growth of Small Manufacturing Firms: Perceptions on Japanese Owner/ Managers. Journal of Enterprising Culture, 4 (4), 351-361.

Wright, M., Hmieleski, K.M., Siegel, D.S., \& Ensley, M.D. (2007). The Role of Human Capital in Technological Entrepreneurship. Entrepreneurship Theory and Practice, 31(6), 791-806.

Yoganandan, G., \& Sivasamy, G. (2016). Challenges of Women Entrepreneurs in Modern India. International Journal of Research in Commerce, Economics and Management, 6 (11), 31-33.

Yoganandan, G., \& Vignesh, T. (2017). Challenges of Young Entrepreneurs. Asia Pacific Journal of Research, 56 (1), 112-115.

Yusuf, A. (1995). Critical Success Factors for Small Business: Perceptions of South Pacific Entrepreneurs. Journal of Small Business Management, 33 (2), 68-73.

Zahra, N. (2013). Implications of Demographic Antecedents in Determining the Motivational Drives among Women Entrepreneurs: A Case Study of Women Entrepreneurs Venturing in Lahore. Pakistan. Asian Journal of Business Management, 5 (1), 163-173. 